\title{
KISÚJSZÁLLÁS, 'THE CULTURAL CAPITAL OF GREAT CUMANIA' - SHRINKAGE, RESILIENCE AND CULTURE-BASED URBAN DEVELOPMENT IN EAST HUNGARY
}

\author{
Tibor KOVÁCS ${ }^{\mathrm{a}}$ \\ ${ }^{a} \mathrm{PhD}$, habil., associate professor, geophilosopher; Eszterházy Károly University, 3300 Eger, Eszterházy \\ Square 1., Hungary, e-mail: kovacs.tibor@uni-eszterhazy.hu
}

Cite this article: Kovács, T. (2017). Kisújszállás, 'the Cultural Capital of Great Cumania' - Shrinkage, Resilience and Culture-Based Urban Development in East Hungary. Deturope, 9(3):122-140.

\begin{abstract}
Motto
"Cultural matters are integral parts of the lives we lead. If development can be seen as enhancement of our living standards, then efforts geared to development can hardly ignore the world of culture."

(Amartya Sen)
\end{abstract}

\begin{abstract}
Demographic changes (population decline) and their (urban) consequences are a real challenge for the small and medium-sized towns of Europe and Hungary. The research question concerning this phenomenon is: how to deal with urban shrinkage and is there any proper and overall answer to this process? Although there is no universal cure for the maintenance and development of these towns, nor for stopping demographic shrinkage, resilience and local culture can provide good conditions to deal with the urban issues raised. Kisújszállás, the cultural capital of Great Cumania can be a good example of how the function-extending renewal of a historical building of the town can strengthen its retaining power and how it can also contribute to increasing the attractiveness of the settlement, all in all, making it a more attractive and viable place to live in.
\end{abstract}

Keywords: Kisújszállás as a shrinking town; resilience; endogenous resources; new approach: culturebased urban development

\section{INTRODUCTION}

\section{The problem of shrinking towns in Hungary and Europe}

'Towns decline not because their industries disappear but because there are no new industries to be created instead of the old ones.' (Jacobs, 1969)

In the post-modern era in most parts of Europe (including Hungary), besides the deindustrialisation and de-economisation of certain regions and settlements the above motto can be connected and completed with the demographic transformation and decline of towns (population shrinkage, migration, aging population), which can be characterised by the dilemma of 'decreasing population - decreasing abilities (?)', let alone the issue of maintaining, developing and making viable such small towns in the middle and the long run. 
We can find diverse international literature related to worldwide shrinkage (e.g. Bernt, 2009; Bernt et al., 2012; Couch et al., 2012; Martinez-Fernandez et al., 2012; Neill \& Schlappa, 2016; Reckien \& Martinez-Fernandez, 2011, etc., and the author of this article also has some publications concerning demographic shrinkage in towns, e.g. Kovács, 2014; Kovács, 2016), shrinkage is average and complex at the same time, each and every settlement has its own set of problems, however, the unique problem of how to be viable is closely connected with a really fashionable theory (and potential practice) of present days, the socalled resilience, adaptable to settlement development as well, the use of which in urban development can give the answer how to handle shrinkage and its complex negative consequences.

In order to overcome the inherited and still constantly generated problems of how to run and develop settlements, the majority of the Hungarian (small) towns, having their serious social-economic problems mentioned above, was involved in efficient (yet not always useful and sustainable) activities of gaining sources from the European Union. They have focused mainly on physical-material developments, overshadowing the development of local human resources, which seems to be a rather short-sighted approach.

At the same time, the future-oriented, new strategic way of thinking, planning and implementation focuses not only on material developments with an engineering aspect but it has a complex socio-philosophic approach as well. It would consciously plan the potential penetration points of the town taking into account the special qualities, endogenous resources, local intellectual potential and the capital involved in the existing cultural symbols and manmade heritage of the given settlement. As Ghilardi stresses: 'cultural planning has to be part of a broader strategy of local development and to create linkages with urban planning, economic policy, industrial policy etc' (Ghilardi, 2005). More precisely and holistic, as Tamás Lukovich wrote in a perfect way in 2001: 'Planning a town is planning its culture.'

In my study I will mention physical developments, too, but my main approach of culturebased urban development is to analyse the town as a symbol (as the term involves this kind of approach). To justify and prove this approach let me give an adequate definition: 'a town is not a mere collection of dimensions given mostly by measurable parameters, perceptible and extended in time and mostly in space, [but] also a separate entity, not or partly comparable with something else, a closed universe which can be comprehended only by its unique qualities.‘ (Gyáni, 1995) 
As we see, Kisújszállás, the typical town of Great Cumania ${ }^{27}$, 'comprehended by its unique qualities' can also be a 'good example', a positive case study, at least partly. The town sees it clearly that "with the disappearance of the patterns related to the industrial periods there is a way to reform the once existed 'immaterial' role' (Frey 1993, Drennan 2002), thus the town can start its way to become an attractive, viable, sustainable and resilient town in the middle and the long run, with the developments based mostly on the town's cultural qualities. Adopting conscious, culture-based urban development Kisújszállás wishes to become the leading settlement of the region, in the field of culture (i. e. in Great Cumania, which is also a symbol). Several strategic developments concerning culture have already been accomplished according to this new concept; the study below gives an outline of this process.

\section{Culture as a tool of the $21^{\text {st }}$ century urban development}

The postmodern period requires the existence and adaptation of different resources compared to the economy of the previous period of Fordism. Nowadays, the conditions for local and regional development do not depend only upon hard infrastructures but on soft infrastructures, among which culture occupies a privileged position. Today, motors of competitiveness and sustainable development are parameters like: quality of life, natural environment, social solidarity, cultural activities and services and the broad participation in them by social groups, protection and innovative valorization of heritage, the creation of 'cultural clusters': such clusters is advisable to be developed around cultural heritage resources (Arvanitaki 2007, 7).

Especially since 2000 - from local to international-scale, and involving scholars, practitioners, planners, and policy-makers at various government levels - culture is gradually becoming recognized in principle as a cross-cutting issue in local/urban sustainable development (Duxbury et al. 2016, 7) (see Fig. 1.).

\footnotetext{
${ }^{27}$ It is one of the typical cultural-ethnic regions of Hungary on the Great Plain, east of the river Tisza. Its ancient inhabitants were the originally nomadic Cuminians who might have settled more than 300 years after the Hungarians in the country badly stricken by the Mongolo-Tatarian invasion. Today agriculture plays an important role in its economy, it is above the average in the Hungarian national economy. As for its socioeconomic development index as a whole, it is a semi-peripheral region, below the national average.
} 
Figure 1: How culture contributes to development

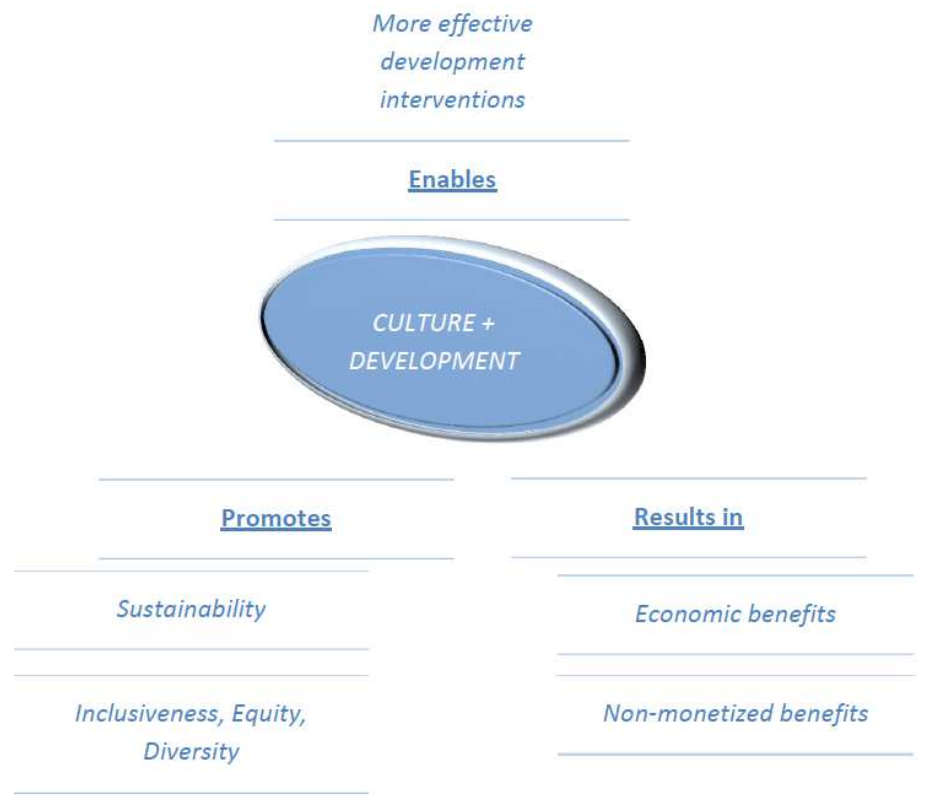

Source: URL 1

Culture-led development also includes a range of non-monetized benefits, such as greater social inclusiveness and rootedness, resilience, innovation, creativity and entrepreneurship for individuals and communities, and the use of local resources, skills, and knowledge (URL 1, 4).

From the point of view of urban development it is a central issue and it will still be in the future that cultural economy is one of the most dynamically increasing, typical element of the (post)modern urban economy (Süli-Zakar et al. 2006). Today, many cities use cultural heritage and cultural events and institutions to improve their image, stimulate urban development, and attract visitors as well as investments (URL 1, 4). It must be recognised that 'culture is a huge business. It is one of the leading sectors of the post-Fordist economic revolution and the base of several programmes related to town renewal' (Scott, A., quoted by Süli-Zakar et al. 2006).

Creating urban culture in a planned, thoughtful way and its effective marketization can be a significant base regarding the viability, sustainability, resilience and future providing of the very often shrinking settlements as cultural economy has different components, can be utilised in a complex way (traditional cultural services; cultural-products industry) (Süli-Zakar et al. 2006). 
Local traditions, festivals, ethnographic attractions can mean the enhancement of tourism and the handicraft activities which were less successful in the period of industrial mass production can revive as well (Süli-Zakar et al. 2006). Due to the symbolic, image-creating and image-enhancing feature of cultural economy it is able to generate such appeal which has an impact on the society and economy of the town.

It is worth mentioning that urban cultural economy is especially sensitive to the quality of the local society, i.e. to the quality of the human resources base.

Another key element of the development of cultural economy is the active politics in this field of the local government, the representative of the local community. The prime role of 'smart' local public administration can be overstressed, as well as the creation of inclusive partnerships. At this point, the contribution of culture is considered a key factor in mobilizing local structures and building up social consensus (Arvanitaki 2007, 7). It is obvious that the conception and implementation of a strategic cultural policy linked to the development of a city stems mainly form enlightened and dynamic local leaderships (Parkinson \& Biankini 1994).

It can be for instance raising cultural expenditures, reorganising the cultural institutions of the town, increasing their efficiency, growing the number and quality of cultural events and revitalising man-made heritage using extended functions (Süli-Zakar et al., 2006), contributing to the improvement of the living standard of the town.

The promotion of culture by the towns, as a public policy serving both social and development targets, has become an imperative of our times: how to link local development with culture, this is what Cultural Planning is about (Arvanitaki, 2007, 7). The more the cultural sector is organically and heuristically integrated into strategic urban policies the better it can help the latter in achieving its objectives (Arvanitaki, 2007, 4).

\section{Resilience - a fashionable term in settlement development}

Each and every era has their own trendy words, so does science: new expressions emerge, old, forgotten ones come to the front or terms which were used in other disciplines penetrate and become legitim in the fields where prior the given term was unfamiliar.

Such an expression in social sciences is the so-called 'resilience'. Without explaining it and its background content in detail (Holling, 1973; Bourbeau, 2013; Chandler, 2013; Joseph, 2015; Neocleous, 2013; do it very often, sometimes arguing with each other, Fejérdy \& Karvalics, 2015, Kuslits 2015, Székely 2015 also, quoting them), a brief analysis has to be 
shown to know what the word actually means and what place this concept can have in the category of settlement development.

The original meaning and usage of the word 'resilience' is due to medicine: it is a phenomenon and capability resulting in recovery after illness, gaining the original state or something very similar. Even in this context it is worth noticing the special features of resilience which later on were revealed and introduced by studies and analyses in different fields (Fejérdy \& Karvalics, 2015, 114):

- dual nature (capability and process appear together, unseparatedly - capability in a historical, process in a cyclical way)

- complexity (the evident existence of holistic approach)

- contextualisation (each resilience situation can exist only in the totally unique combination of external impacts and internal capabilities)

- cyclicity (Fejérdy \& Karvalics, 2015, 115).

If we need an extended definition related to resilience, adaptable for urban development, the following can be the most accurate: 'Resilience is the flexible adaptation of an individual, an organisation [or a settlement] to the external negative effects. Plasticity and stability at the same time... It is the capability which is experienced when negative life events happen to people and they can regain their state of balance, if they react adaptively. Thus the harmful impacts of vicissitudes can be minimised or ceased. During the adaptive process the individual, the organisation [or the settlement] solves problems, learns, renews and develops. The new state of balance is not equal with the old one as in order to fight efficiently the anticipated similar impacts in the future it is necessary to be prepared for it' (Izsó 2014).

When analysing resilience it is also important to take into account the capability approach (Sen 1993). Adapting this theory for settlement development as well, it is important to map local human resources as thoroughly as possible, to utilise them and rely on capabilities. As well as natural environment/natural capital, intellectual-cultural or man-made heritage can also be interpreted and mobilised only in the context of human intervention/responsibility (Bajmócy 2012). A high level of resilience can be achieved only by a high level of social cohesion and relying on 'extrasomatic' capabilities. Besides general similarities, each and every town has their specific structure of capabilities: these are such special features or specific combinations of these which are typical of only the given settlement and its residential community (Fejérdy \& Karvalics, 2015, 119). 
It is characteristic that everyday problems and tasks of urban management in a routine-like world of idealess reflections to the changes in 'statistics' population data (e.g. demographic shrinkage) the never-ceasing exploration, evaluation and re-evaluation (depending on changing circumstances) of 'capabilities' are neglected.

At the same time, the strategic aim of how to enhance retaining power and resistance can be seen in slogans rather than in consciously composed middle-term programmes (Fejérdy \& Karvalics, 2015, 119).

Yet it can be easily understood that even one single (!) citizen's special 'capability', a 'capability' based on one single historic building or one single specific natural resource characteristic only of the given settlement - can be the starting point or buoyant force of strengthening resilience and creating new strengths. To achieve this aim it is not enough to think in point-like capabilities, it is inevitable to base on processes, recognising their cyclic nature and identifying properly the essential characteristics of particular cycle stages (Fejérdy \& Karvalics, 2015:119).

\section{Combining culture and resilience - focusing on urban historic buildings}

'All urban communities, whether they have developed gradually over time or have been created deliberately, are an expression of the diversity of societies throughout history.'- it is stated in the very first sentence of the introduction in the international charter acknowledged in 1987 of Protecting Historical Towns (Washington Charter 1987). As (man-made) cultural heritage and resilience started to be incorporated in the scientific and pragmatic development discussion next to each other, combined with preparations for catastrophies and renewals after them, combining material and social aspects - existing mutually - can be said almost evident here (Fejérdy \& Karvalics, 2015, 123): ‘... just like biological diversity increases the resilience of natural systems, similarly, cultural diversity is also able to enhance the resilience of social systems. Preserving cultural diversity for the future together with all the knowledge, innovation and prospects it offers will increase the capacity of human systems which enables them to adapt to changes or to live together with them. Cultural heritage as the key element of cultural diversity is a crucial aspect in defining the strategies serving the development of community resilience... Resilience is meant both for men both man-made and natural environment; it is shaped by physical and social factors as well.' (URL 2)

Not only was resilience put into the dictionary of heritage protection, but it also became a trendy topic immediately (Ripp 2013). What has been thought over during the past few years 
in connection with historic buildings as an outstanding element of how to create urban image and identity sounds especially exciting (Fejérdy \& Karvalics, 2015, 123).

In the life of towns and their communities individual identity consciousness has a determining role; their adaptation cycles can go on being in action, in other words, we can talk about renewal only if this specific identity exits and has its influence. Historic buildings are the most important visible (in addition, feasible for different functions) attributes of this identity - due to their physical existence, stability, real and symbolic meanings (Fejérdy \& Karvalics, 2015, 123). Physical existence includes significant 'inertness'. It is even expressed in the word 'immovable (estate)'. For resilience it is a kind of stabilising power similar to the ballast of the well-known toy (tumbler) which always puts the figure into its vertical (normal) position, thus turning on its peg. This effect - under certain circumstances - predominates even if the physical state of the given buildings is not satisfactory or they have partly or completely been obsoleted: the values they represent cannot be materialised and will not cease to affect in this case either. Physical and moral obsolescence of historic buildings must have been one of the best indicators of the fact that resistence started weakening and time has ripen for activating the factors strengthening resilience (Fejérdy \& Karvalics, 2015, 123).

To treat the complexity of the problems in Kisújszállás as a shrinking small town new ways have to be found based on the above introduced theories. It is true for this town as well that in the field defined by the complex processes of overall social-political-economic changes (together with the decreasing EU sources) it is becoming more and more important for the town what kind of local social (material and intellectual) cultural reserves it can mobilise and how it will be able to maintain and provide in the future the welfare or wellbeing its citizens expect to have (Gébert 2012).

\section{OBJECTIVES AND METHODS}

\section{The research question}

As we could see above, demographic changes (population decline) and their (urban) consequences are a real challenge for the small and medium-sized towns of Europe and Hungary. The research question concerning this phenomenon is: how to deal with urban shrinkage and is there any proper and overall answer for everyone to this process? 


\section{The aim of the research}

Trying to give an answer to the question, the aim of this research is to introduce the demographic changes of the past decades of a typical Hungarian country town by the example of Kisújszállás, the reasons of its shrinkage, the problems it has caused and the urban development alternatives which might solve these problems, focusing on the intellectual and material cultural heritage of the town as developmental fund.

According to it my aim is to examine - at least give an outline of - the resilience capability of the town (focusing on the man-made heritage, historic buildings); the possibilities and results the town has for its culture-based development and what future challenges it can face in this traditionally Great Cumanian town.

\section{Research methodology}

During the research I used the following methods:

- processing the related national and international bibliography

- analysing the Hungarian central and the local normative controls concerning urban development

- collecting, analysing and applying the related central and local statistical data (data service of KSH (Hungarian Central Statistical Office), Mayor’s Office of Kisújszállás)

- analysing relevant local developmental documents and their plans (current economy development programme, urban design, the analysis of a proposal on local sustainability concept and analysing the plans of tourism marketing)

- assessing tender documents

- questionnaires (on cultural habits of Kisújszállás' inhabitants - non-representative due to the extremely low willingness of respondants...)

- prominence examinations (interviews: mayor, full-time vice-mayor, notary, vice-notary, CEOs of Redoute (Vigadó) and Kumánia Thermal Bath Ltd.)

- 'experienced geography' - the method of 'mingling with common people'.

\section{RESULTS}

\section{Problems, reasons and consequences of the town shrinkage in Kisújszállás}

Kisújszállás, the subject of this study, is a Hungarian settlement, a typical country town lying 150 kilometres east of Budapest and 80 kilometres west-south west of Debrecen, which is the 
second largest town in Hungary. It boasts with its man-made and intellectual cultural heritage and the colourful Great Cumanian traditions - partly living today.

During the research I had to state that Kisújszállás (adapting to the population trends of certain European regions, including Hungary as well) has had severe demographic vulnerability, population problems for several decades (both in quantity and quality).

Analysing the demographic data of the settlement we can state that the population of the town reached its peak in the $20^{\text {th }}$ century, in 1930, with inhabitants of 14532 (Vincze 2004) since then up to now this number has been falling: in the year of the regime change there were 13159 inhabitants yet today there are only 11092 (see Tab. 1).

Table 1: Population decline in Kisújszállás in the last decade

\begin{tabular}{|l|c|c|c|c|c|c|c|c|c|c|}
\hline \multicolumn{1}{|c|}{ Year } & $\mathbf{2 0 0 7}$ & $\mathbf{2 0 0 8}$ & $\mathbf{2 0 0 9}$ & $\mathbf{2 0 1 0}$ & $\mathbf{2 0 1 1}$ & $\mathbf{2 0 1 2}$ & $\mathbf{2 0 1 3}$ & $\mathbf{2 0 1 4}$ & $\mathbf{2 0 1 5}$ & $\mathbf{2 0 1 6}$ \\
\hline $\begin{array}{l}\text { Nr. of } \\
\text { inhabitants } \\
\text { (head) }\end{array}$ & 12 & 11 & 11 & 11 & 11 & 11469 & 11 & 11 & 11 & 11 \\
\hline
\end{tabular}

Source: KSH, Mayor's Office of Kisújszállás

The reasons can be different - European and Hungarian social-political traumas, economic problems, culture-based changes in fertility rates, etc. From the analysis of statistical data we can see that in Kisújszállás during the past decades the number of population has decreased by 3000 people (what further worsens the situation is that certain inhabitants registered in the town are not habitually residents). Besides, ageing index was high even in $2000,80,4 \%$, and it rose to one and a half times in 2013: 130,9\%.

The population shrinkage which can be seen clearly from the above data can have the following main reasons: the negative balance of natural growth and migration difference (almost every year since 1990); fertility instability/imbalance; migration of young(er), (more) qualified workforce into larger towns or into the capital city; ageing. In addition, the increasing reproduction or settling from other places into Kisújszállás of the declassed layers i.e. people at the edge of the society or those totally marginalised can mean a potential risk of danger for the town population.

As a conclusion: comparing the relevant demographic data I could state that among the settlements of Karcag district the demographic processes of Kisújszállás are the most disadvantageous (see Fig. 2) - at least regarding its quantitative indicators. 
Figure 2: Changing number of population in the Karcag microregion (1990-2011)

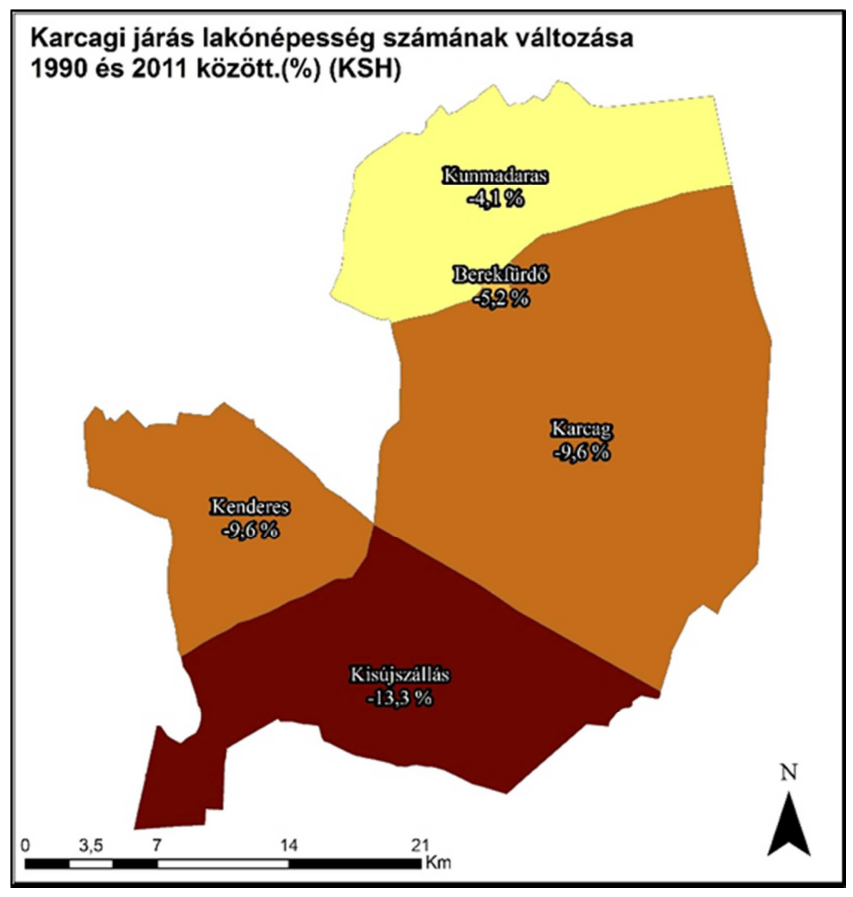

Source: KSH

\section{Barriers of urban development and its future prospects}

Besides the above demographic data which are well-measured by statististical figures, though leave the qualitative side in the background, unfortunately, there are certain typically Hungarian and local characteristic features counteracting a western-European type of grassroots, iterative and productive urban development, which could handle even shrinkage. These problems are the following:

- applying mostly traditional urban planning/developing methods (which cannot be innovative enough due to the national regulatory constraints, not to the local ones)

- conflicts of interests between certain determining persons in urban development (in politics, economics, on all fronts)

- mistrust of actors potentially interested in urban development

- entrepreneurial slowness, disability of renewal, lack of will combined with a kind of retrograde incomprehension

- incomprehension of local inhabitants or their acquired helplessness (e.g. the town has a vivid craft activity, producing typical local goods, yet only l'art pour l'art as their marketisation is negligible since there is not an umbrella organisation to co-ordinate these activities and it lacks the proper marketing activity either)

- a developing yet still inappropriate urban and tourism marketing activity 
- as a summary, inadequate quality of local human resources.

As a result of these complex social-demographic difficulties the problem of local shrinkage is registerable today and - if present tendencies go on like this - will increase in the future, that is

- infrastructure, the maintenance of man-made environment and the ageing local society will become more and more expensive ('decreasing population - decreasing capabilities'?)

There is a threat of the following:

- creating a malformed local society which is declining demographically, morally (social anomia) and economically (as it is impoverishing, financially vulnerable, reproduces poverty many times) and unable to maintain itself

- a complex urban social-economic-environmental decline

- overall depopulation.

\section{Reactions to the emerging urban challenges}

In order to set the sustainable demographic development of the local society on the right track the settlement (including the local government, enterprises, civilians, everybody) has to face the facts: i.e. to recognise and accept the fact of shrinkage itself and according to it handling it based on local co-operation.

From the point of view of demographic renewal the following could mean a factual solution to the settlement: retaining (highly qualified) young people, attracting them to the town and bestowing them as high labour market competences as possible, providing workplaces to employ them, stimulating fertility rate, offering preferential housing. However, these are rather complex expectations, very often beyond the competences of the local government and solutions should not always be expected from the management. During my research it was revealed that a part of the urban population, mostly low-skilled, uncompetitive even on the periphery, has no idea of how to develop - they show little willingness to learn and work.

Though the town leadership does not want to 'surrender' to the anticipated future crisis caused by the complex problems outlined above. To solve the problems it has had a strategy of urban development for more than a decade which regards the development of culture such priority that can become one of the most efficient tools of fighting shrinkage and creating a viable and resilient town, ready for renewal. This development of culture can include 
cultivating of intellectual heritage, publishing books, organising events, granting scholarships for talented local youngsters, renovating historic buildings by function-extension, etc.

This culture-based developmental approach can provide relatively good possibilities for a country town with rich traditions as Kisújszállás is, since in the $21^{\text {st }}$ century culture can be one of the most important 'soft' factors and the analysed town has been rich in such factors. The unique and immediately mobilisable intellectual heritage includes the work of István Csukás, the nation-known fabulist, who was born in Kisújszállás. Concerning man-made heritage we have to mention the building of Vigadó, yet regarding production culture local rice growing is a resource.

\section{Urban development with question marks}

Kisújszállás experienced the political transition as a shock - just like the majority of the country. Local economy suffered a sharp fall; urban population was unable to face the radically new socio-political, economic and environmental challenges in an adequate way. The transformation was backward and odd: the first freely elected local government was engaged in managing crisis, the beginning of the 2000s can be characterised mostly by making no progress at all, lacking conceptions and developments - at least concerning urban development.

The real change in urban development was brought by the year 2006: a new, dynamic town management took charge of the leadership, with firm conceptions, visions spanning over political election cycles - and not incidentally, that was the time when important EU tender sources were opened, too, which Kisújszállás made the best use of. The settlement has been accomplishing conceptual developmental ideas, managing the town as an organic unit for more than a decade. However, we cannot merely ignore the existing difficulties: although the settlement has a mature political and professional-administrative management, it composes and implements developmental conceptions based on Great Cumanian traditions, the westernEuropean iterative urban development policy still does not operate well. It is a consequence of course not only of local intellectualism but also that of typical of Hungary as well. Socialisation is slow; the participation of inhabitants is very minimal in dreaming, discussing and realising plans. However, the accomplished investments are usually taken with revulsion by the population; somehow inhabitants would always like to see something else than what is actually being born (the mayor of the town said about it in the interview: 'Whatever we do cannot be good enough'). An additional and crucial difficulty is that although Kisújszállás knows the fact of demographic shrinkage, it still does not recognise it. For the general public 
and for politicians it can mean only a negative context, a kind of loss, it does not have any positive perception in common talk. The town has several modern, developmental documents being implemented conceptually, yet that one does not exist, the starting point of which would be population shrinkage and which would talk about the developmental ideas reacting to this.

Despite the above constraints of facts, the lack of civilian mentality, the very few grassroots initiatives and the shortcomings of local material resources, Kisújszállás was able to reach spectacular results in the EU developmental period of 207-2013: it gained different developmental applications one after the other. The biggest and most spectacular part of these was the three-stage town centre rehabilitation project which was completed in 2015. I would like to analyse the most important project and the results of the investment in the next part.

\section{How to become the centre of social interaction from a blight place - urbanistic renewal in the name of culture}

The city centre of Kisújszállás was renovated using about 1,2 billion forints (cca. 3,9 million euros) in the 2010s: these were spectacular, 'aestheticising urban developments' according to many. It is a fact yet these involved not only the development of immovable estates but also the renovation of the parks and green areas in the city centre, let alone the accomplishment of cost-effective energetic developments.

The most important - and at the same time the most debated, most expensive and most time-consuming - investment was the renovation of the former Theatre and Redoute (Vigadó), one of the emblematic buildings in the city centre. The Art Nouveau style building was erected in 1911-12 and had several functions even that time: it served as a theatre, a cinema, housing different social events. Later on theatrical performances were ceased, after the 1950 nationalisation its main profile was the cinema. Sometimes the plays of local troupes were performed and school celebrations, assemblies were also held in the great hall. Following the change of the political regime, the building once significant not only in Kisújszállás but also in the wider area, suffered from long agony and unworthy functions. Finally its calvary resulted in making the building one of the shameful places of the town and it was closed in 2000. Its Cinderella-dream lasted one and a half decades and there was only very little missing to demolish it physically...

However, the town leadership functioning since 2006 did not let this unrivalled value be vanished and taking the advantage of tendering they renovated the building bringing back or even surpassing its former glory. The management based on the Great Cumanian selfconsciousness, the unique and rich traditions of the town, the culture as retaining power on the 
whole and on the long-term concept according to which Kisújszállás as the $6^{\text {th }}$ biggest town in Jász-Nagykun-Szolnok county and the $2^{\text {nd }}$ biggest of Great Cumania should become the 'cultural capital' of the region.

It is important to emphasise that besides the physical renovation of the building it was a crucial aspect to make the Redoute (Vigadó) the multifunctional cultural centre of Kisújszállás and its wider region: according to it the building has a theatre and a concert hall, a 3D-cinema, a TV studio, children's area for activities, a dance hall, a bowling alley, a canteen and a café.

During the research I stated that since the opening of the Redoute of Kisújszállás in 2015 the following theses have been proved (based on Fejérdy \& Karvalics, 2015, 124):

- the building represented the continuity of the Great Cumanian self-consciousness in Kisújszállás and the symbol of what the cultural desire of the local peasant-civilian society of the last century was able to create, thus the building as a physical asset and as knowledge, experience and creativity accumulated on the spot enhanced the local capability of resilience

- being a significant historic building it was incorporated in the mind and intellectual heritage of consecutive generations; locals did not let it be lost but as 'resiliencepotential' long-time dormant, revitalised it the first time they had the opportunity to do so

- the renovation of the Redoute was not an 'aetheticising' building renovation project simply for itself, the town did not handle it as a museum. During the renovation it was partly reinterpreted and due to its multifunctionality it can provide space both for satisfying the really diverse popular and highbrow cultural needs

- the building gives a place for the great many cultural events of the town and its region not only in its physical form: it has a symbolic overplus announcing and establishing the slogan according to which 'Kisújszállás wishes to become the cultural capital of Great Cumania' even in the short-run in the region, moreover, in the Szolnok-Debrecen region

- utilising the knowledge and experience of the building, keeping them alive by appreciating and maintaining the values, Kisújszállás - at least partly- reacted in a resilience-increasing way to the challenges of demographic processes of the present and the future - knowing that it is far from the best solutions to the complex problems of urban shrinkage but still a landmark on the way towards creating a 'viable and sustainable' town. 
Concerning this function-extending investment it can be stated that the town has actually accomplished a development which corresponds theoretical-scientific demands as well, i.e. the town has found one of its cultural resilience-centres of gravity which has been renovated properly and utilised to make the place more attractive and viable.

\section{DISCUSSION}

How would it be possible to go on in formulating the sustainable and developmental possibilities of a shrinking town which focus on and use local cultural heritage in a broad sense?

Applying the following scientific and practical methods and tools seem to be reasonable:

Scientific methods promoting urban development:

- KRAFT-methodology (it is not sufficient itself, but combining it with a resilience research it can provide appropriate points to formulate real developmental conceptions based on local capacity and possibilities):

○ surveying social creativity features

○ surveying and identifying social capital and network potential (quantity, intensity, features and quality)

$\bigcirc$ analysing sustainability potential

- carrying and extending resilience-tests

- applying capability approach in planning

- using the long tail model: exploring the 'global capital' role of Kisújszállás in any fields of social-economic life

- finding and utilising niche in order to strengthen resilience: further exploration and analysis of historic buildings, local rice growing and the work of István Csukás, utilising them in order to develop the town and retain population.

Tasks of the practical side to make urban development more efficient and successful:

- involving local large enterprises, creating win-win situations

- continuous, 'forced' communication with the inhabitants - finding the influential opinion leaders, having dialogues with them. 


\section{CONCLUSION}

One of the biggest and ever increasing challenges of Hungary and Great Cumania is how to develop (or simply maintain) small- and medium sized towns in a general social-economic environment which tends to be rather negative. As a conclusion we can state that there is no final and overall solution concerning the urban population's shrinking - every settlement has to find its own path towards the solution which is absolutely individual and unique.

However, agreeing with the view of Rem Koolhas ('All that has been left for us is the city'), Kisújszállás can perceive (yet does not approve at political level) the complexity of the problems caused by shrinkage. Although a complex and mature town strategy having definitely shrinkage as its starting point is still not available for the settlement, a conceptual urban development process has been in progress for more than a decade to make Kisújszállás a more viable and attractive place to live in. In this process the Great Cumanian traditions and the local culture as a symbolic developmental overplus are emphasised.

As a part of the cultural heritage Kisújszállás (defining itself 'The cultural capital of Great Cumania' since 2016) possesses such historic buildings which can form the basis of the town resilience-capability and the accomplishment of the urban development activity based on it. In the past few years the town has renovated the building of the iconic Redoute (Vigadó) within the framework of the function-extending renewal of the town centre, thus it has become the multifunctional cultural centre of the settlement. Though the building has been open for the public only for two years, it seems to be a success story: it has become an attractive centre not only for the inhabitants of Kisújszállás but also for those of the region. It helps the town to fulfil the vindicated title of the slogan of 'Cultural capital of Great Cumania' with real content and on the whole, to create the town a resilient, more viable and attractive settlement.

\section{REFERENCES}

Arvanitaki, A. (2007). Urban Development Planning and Culture. ECCM Symposium: 'Productivity of Culture', Athens, 18-20 October 2007.

Bajmócy, Z. (2012). A képesség-szemlélet alkalmazásának lehetőségei a regionális tudományban. In: Rechnitzer, J. \& Rácz, Sz. (szerk.). Dialógus a regionális tudományról. Széchenyi István Egyetem Regionális Gazdaságtudományi Doktori Iskola - Magyar Regionális Tudományi Társaság, Győr, pp. 18-30.

Bernt, M. (2009). Partnerships for Demolition: The Governance of Urban Renewal in East Germany's Shrinking Cities. International Journal of Urban and Regional Research 3. pp. 754-769.

Bernt, M., Cocks, M., Couch, C., Grossmann, K., Haase, A. \& Rink, D. (2012). Shrink Smart. Policy Response, Governance and Future Directions. Research Brief No. 2, Helmholtz Centre for Environmental Research - UFZ, Leipzig. 
Couch, C., Cocks, M., Bernt, M., Grossmann, K., Haase, A., \& Rink, D. (2012). Shrinking Cities in Europe. Town \& Country Planning, pp. 264-270.

Drennan, M. (2002). The Information Economy and American Cities. Baltimore, MD: Johns Hopkins Press.

Duxbury, N., Hosagrahar, J. \& Pascual, J. (2016). Why Must Culture Be at the Heart of Sustainable Urban Development? United Cities and Local Governments (UCLG), www.agenda21 culture.net (downloaded: 11 September 2017)

Fejérdy, T., \& Karvalics, L. Z. (2015). Kis- és közepes városok kulturális rezilienciasúlypontjai. Replika (94), 2015/5. szám, pp. 113-127.

Frey, W. H. (1993). The New Urban Revival in the United States. Urban Studies, 30(4/5), $741-774$.

Gébert, J. (2012). A jólét mérésének elméleti alapjai és problémái. In: Bajmócy és tsai (szerk.). Regionális innovációs képesség, versenyképesség és fenntarthatóság. JATE Press, Szeged, pp. 303-317.

Ghilardi, L. (2005). 'Culture at the Centre: Cultural Planning, a Strategic Approach to Successful and Sustainable Community-based Regeneration in Scotland', Noema Research and Planning Ltd, London

Gyáni, G. (1995). Bevezető. In: Gyáni, G. (szerk.) A modern város történeti dilemmái. Csokonai Kiadó Kft., Debrecen, ISSN 1219 1086, ISBN 963260074 6, p. II.

Izsó, G. (2014). Human Dynamics - Aug. 28. http://humandynamics.hu/index.php?option =com_content\&view=article\&id=84:resilience-azaz-reziliencia\&catid=39:vezetoicoaching (downloaded: 20 April 2017)

Kovács, T. (2014). A városfejlődés „új“ iránya közép-európai nézöpontból. Magyar Tudomány, 175(8), 966-973

Kovács, T. (2016). Demographic Changes and Their Spatial-Settlement Consequences: Lessons from East Germany and Hungary. Deturope, 8(3), 108-123.

Kuslits, B. (2015). Reziliencia társadalmi és ökológiai rendszerekben. Alkalmazott Pszichológia, 2015, 15(1), 27-41. DOI: 10.17627/ALKPSZICH.2015.1.27

Lukovich, T. (2001). A posztmodern kor városépítészetének kihívásai. Pallas Stúdió, Budapest, $193 \mathrm{p}$.

Martinez-Fernandez, C., Kubo, N., Noya, A., \& Weyman, T. (eds.) (2012). Demographic Change and Local Development: Shrinkage, Regeneration and Social Dynamics. OECD Working Papers, Paris, OECD/LEED.

Neill, W.J.V. \& Schlappa, H. (eds.) (2016). Future Directions for the European Shrinking City. RTPI Library Series, Routledge Taylor \& Francis Group, London.

Parkinson M. \& Biankini, F. (eds.) (1994). 'Cultural Policy and Urban Regeneration', Manchester, University Press

Pirisi, G. \& Máté, É. (2014). Zsugorodó kisvárosok - kincstári optimizmus. In: László M. (főszerk.). Területfejlesztés és Innováció, 8(2), 28-39 http://www.terinno.hu/szamok/ teruletfejlesztes_es_innovacio_2014_2.pdf

Reckien, D. \& Martinez-Fernandez, C. (2011). Why Do Cities Shrink? European Planning Studies 8., pp. 1375-1397.

Ripp, M. (2013). Crisis: an Opportunity for Historical Cities - Built Cultural Heritage as a Factor of Urban Resilience. HERMAN Project Report. http://www.hermanproject.eu/outcomes/other-documents.html (downloaded: 20 April 2017)

Sen, A. (1993). 'Capability and Well-Being'. In: Nussbaum, M. \& Sen, A. (eds). The Quality of Life, Clarendon Press, Oxford, pp. 30-53.

Süli-Zakar, I., Ekéné, Zamárdi I., Kozma, G., \& Teperics, K. (2006). Debrecen kulturális gazdagsága és gazdasága. In: Kókai S. (szerk.). Földrajz és turizmus. Nyíregyházi 
Föiskola Természettudományi Főiskolai Kar Földrajz Tanszéke, Nyíregyháza, ISBN 963733631 1, pp. 313-334.

Székely, I. (2015). Reziliencia: a rendszerelmélettől a társadalomtudományokig. Replika (94), 2015/5. szám, pp. 7-23.

URL 1: UNESCO (2012). Culture: a Driver and an Enabler of Sustainable Development. Thematic Think Piece.

http://www.un.org/millenniumgoals/pdf/Think\%20Pieces/2_culture.pdf (downloaded: 11 September 2017)

URL 2: Fourth Session of the Global Platform on Disaster Risk Reduction (Geneva, 18-23 May 2013)

http://icorp.icomos.org/images/documents/Heritage\%20and\%20Resilience\%20Book\%2 0for\%20GP2013\%20Disaster\%20Management.pdf (downloaded: 20 April 2017)

Vincze, S. (2004). Hogyan változott Kisújszállás népessége és iskolázottsága az elmúlt században - föként annak második felében? In: Ducza L. és tsai (szerk.). Kisújszállási Nagykun Kalendárium a 2004-es szököévre. Kisújszállás, pp. 267-277.

Washington Charter (1987) (Charter for the Conservation of Historic Towns and Urban Areas), https://www.icomos.org/charters/towns_e.pdf(downloaded: 20 April 2017) 